\title{
PENGUJIAN EFEK MARKETING MIX DAN PERLINDUNGAN PADA SEKTOR RETAIL DI KOTA BATAM SEBAGAI SUATU KAJIAN SINTESA META ANALYSIS
}

\author{
${ }^{1}$ Putu Hari Kurniawan, ${ }^{2}$ Heryenzus \\ ${ }^{1}$ Universitas Putera Batam \\ harifebby@gmail.com
}

\begin{abstract}
This research is to purpose the small retail distribution who have always worked to establish close relationship with customer throught the Retail Marketing mix. Thus the literature has a long tradition of testing the effect of various instrument on Retail Patronage. This Meta-Study synthesis prior research into one comprehensive frame work. We use 120 responden which evaluate from 4 district extracted from 250 shopper to test the impact of 24 marketing mix instrument on retail patronage. Specifically, we investigate the direct and indirect effect in marketing mix of these instrument display to observe strongest effect of most outcome variable whereas price, communication service, WOM, hedonic behaviour, retail environment and other especially in Batam. To resolve the problem in the research we used Structure Equation Model (SEM) with Covarian basic approach.
\end{abstract}

Keywords: Marketing Mix, Retail Patronage, Hedonic Behaviour, Store Environment, Meta Analysis

\begin{abstract}
ABSTRAK
Usaha retail selalu beraktivitas melakukan hubungan dekat dengan pelanggan terutama hal ini akan dikaitkan dengan Marketing Mix. Dengan demikian, studi literatur selama ini memiliki sebuah kebiasaan untuk mengecek dan menguji efek dari berbagai instrument yang melindungi aset retail. Dengan penerapan Meta Analisis penelitian ini lebih menelaah dan memprioritaskan observasi menjadi satu kesatuan dengan merangkum kajian menjadi kerangka komprehensif hasil penelitian terdahulu yang diperdalam lagi dengan kajian yang lebih luas. Di penelitian ini digunakan ukuran efek yang direport dari 4 wilayah di saring menjadi 120 sampel yang sifatnya independen untuk mengetest pengaruh instrument marketing mix dalam penerapan perlindungan ritel. Secara spesifik dalam penelitian ini kami mengivestigasi pengaruh secara langsung dan tak langsung pada instrument ini terkait dengan kepuasan terhadap gerai, word of mouth, perilaku hedonis dan Store Environment konsumen di kota Batam. Hasilnya Perlindungan retail memiliki relasi langsung dengan Store Environment. Dalam menyelesaikan permasalahan dalam riset ini digunakan analisis SEM berbasis covarian.
\end{abstract}

Kata Kunci: Marketing Mix, Perlindungan retail, Perilaku hedonis, Store Environment, Meta analysis

\section{PENDAHULUAN}

Retail service (pelayanan eceran) bertujuan memfasilitasi para pembeli saat mereka berbelanja di gerai. Hal hal yang dapat memfasilitasi para pembeli terdiri atas layanan pelanggan, perilaku berbelanja, personal selling, cara pembayaran transaksi yang mudah berupa penjualan dengan kredit maupun autodebet. Di sisi lain juga ad pemenuhan fasilitas penunjang lainnya seperti contoh toilet, food court dan valet parking.

Retail service bersama unsur marketing mix retail memiliki fungsi memenuhi kebutuhan pembeli dalam berbelanja meskipun yang dijual oleh sebuah gerai eceran berupa barang yang kasat mata (tangible). Pada hakekatnya pembeli mencari barang untuk memenuhi kebutuhan misalnya air minum dalam kemasan sebenarnya dibeli untuk menghilangkan rasa dahaga, tetapi aspek pelayanan membuat gerai berbeda rasa dibandingkan dengan gerai lainnya. Karena itu pelayanan menjadi salah satu unsur dalam suatu moment belanja seseorang maupun suatu keluarga secara umum. Ada tiga unsur yang terdapat dalam suatu barang atau jasa yang dibeli yaitu unsur inti, tangible dan unsur augmented yaitu fasilitas yang mendukung 
Fenomena terkait dengan permasalahan retail terutama segala sesuatu yang melindungi aspek pemasaran barang dan grocery telah menghasilkan suatu yang signifikan terutama dihubungkan dengan teori dan literatur dimana dalam berbagai kajian banyak dikembangkan dan diberdayakan terkait hubungan dekat pelaku retail dengan konsumen terutama pelanggan. Gerai besar atau gerai milik perusahaan perdagangan eceran skala besar dan kecil memiliki tantangan yang sama dengan gerai kecil yaitu bagaimana memikat calon pembeli dan bagaimana menata secara menarik agar bisa menyaingi gerai gerai besar atau pusat perbelanjaan pesaing.

Hal ini memiliki titik tolak yang berbeda dari gerai kecil, gerai besar harus menangani persoalan dalam skala besar seperti penataan barang dalam jumlah besar, penataan interior, penataan cahaya dan lainnya. Tantangan gerai besar adalah bagaimana mengelola suasana (atmosfer) dalam toko sedemikian rupa sehingga tujuan meningkatkan kunjungan tercapai, penjualan bertambah dan citra positif terbangun. Untuk itu perlu diketahui hal hal apa saja yang dapat menunjang terbentuknya suasana gerai sesuai dengan harapan konsumen. Ada dua macam perilaku berbelanja yang menjadi titik perhatian peritel dalam rangka menyiapkan suasana dalam gerai yang sesuai.

Kinerja retail menurut (Hasslinger, Hodzic, \& Opazo, 2007) berpendapat bahwa kinerja retail dapat berfokus dan terjadi pada beberapa tingkat dalam perusahaan. Ia mengatakan bahwa ukuran pada kinerja retail digunakan sangat baik pada bentuk dari tingkatan perusahaan dan keseluruhan ukuran dari kedua duanya kinerja keuangan (pengembalian saham modal) dan kinerja pemasaran terkait dengan posisi image pada persaingan pasar. Hal ini digunakan secara variative pada tingkatan perusahaan dimana unit, asset digunakan pada ukuran kinerja seperti kontribusi dollar per meter persegi pada ruang penjualan. Digunakan secara variative pada tingkat tingkat operasi wilayah gerai atau departemen. Banyak tingkat barang dan kelompok, kategori, garis, bentuk digunakan untuk indikator pembelian dan menjual seperti pengembalian keuntungan bersih pada laba dalam inventarisasi dan produk laba langsung dalam ukuran kinerja.
Pada pembahasan ini kinerja bisnis diukur dengan model variasi instrument yang dikembangkan oleh (Reddy \& Aradhya.S, 2017). Dalam perkembangannya ritel memiliki beberapa fungsi penting yang dapat meningkatkan nilai produk dan jasa yang dijual kepada konsumen dan memudahkan distribusi produk produk tersebut bagi perusahaan yang memproduksinya. Konsumen selalu mempunyai pilihan sendiri terhadap berbagai jenis produk dan usaha. Untuk itu dalam fungsinya sebagai peritel mereka berusaha menyediakan beraneka ragam produk dan jasa yang dibutuhkan konsumen. Retail memiliki fungsi sebagai breaking bulk yaitu memecah beberapa ukuran produk menjadi lebih kecil yang akhirnya akan lebih menguntungkan produsen dan konsumen.

Berdasarkan uraian di atas penulis tertarik untuk melakukan penelitian dengan judul "PENGUJIAN EFEK MARKETING MIX DAN PERLINDUNGAN PADA SEKTOR RETAIL DI KOTA BATAM SEBAGAI SUATU KAJIAN SINTESA META ANALYSIS"

\section{TINJAUAN PUSTAKA}

\section{Instrument Marketing Mix Retail}

Marketing Mix atau bauran pemasaran merupakan istilah yang dipakai untuk menjelaskan perpaduan strategi strategi pembentukan inti system pemasaran sebuah perusahaan untuk mengetahui reaksi pembeli. Penulis menguraikan Marketing Mix dari beberapa ahli menurut (Novak, 2011) "Marketing Mix adalah suatu set variabel dalam rencana pemasaran yang dapat dikontrol dan biasanya dinyatakan dalam bentuk 4P yaitu Produk, Price, Promotion dan Place. Dari definisi tersebut marketing mix merupakan rencana pemasaran yang terdiri dari produk, harga, tempat dan promosi. Menurut (Fieger, 2015) definisikan marketing mix adalah seperangkat variabel pemasaran yang terkontrol dan digabungkan perusahaan untuk mengasilkan tanggapan yang diinginkan dalam pasar sasaran. Ini berarti konsep marketing mix merupakan segala usaha yang dapat perusahaan lakukan untuk mempengaruhi permintaan produknya.

\section{Perlindungan Retail.}

Literatur tentang retail seringkali berfokus pada aspek perilaku dari konsumen 
sebagai point kajian digunakan sebagai acuan untuk mengukur pertahanan atau perlindungan pada gerai yang bersangkutan. Menurut (Sari, Yuli Kumala; Shaari, Zullina Hussain; Amar, 2017). Perlindungan retail banyak didiskusikan para ahli, meskipun beberapa ahli secara lebih luas mendiskusikan pandangan yang lebih luas terkait dengan perlindungan konsumen. Niat untuk menduskusikan dimensi pengganti lebih didekatkan pada hubungan yang lebih singkat antara konsumen dan retailer dalam kajian ini. Awalnya konsep ini dikembangkan secara eksplisit oleh (Ertekin, 2009) dimana secara dalam kajian ini konsep Retail diberikan kritikan tajam terkait dengan deksripsi tentang perlindungan konsumen yang lebih difokuskan secara kuat pada dimensi perilaku. Di dalamnya diabaikan peranan dimensi yang terdekat dimana sebenarnya kajian yang diangkat lebih tertuju pada perlindungan retail seperti faktor sikap dan perilaku konsumen.

Pada umumnya Perlindungan retail dideskripsikan lebih dekat dengan hubungan berkelanjutan antara aspek perlindungan dan eksistensi retail itu sendiri dengan konsumen yang terkait. Dalam konteks retail suatu perlindungan dianggap sebagai acuan pelanggan dalam melakukan aktivitas belanja secara eceran terhadap retail yang bersangkutan. Konsep perlindungan secara umumnya dalam retail ini didasarkan pada fakta yang diperoleh memiliki karakteristik timbal balik diantara beberapa retail yang ditawarkan pada konsumen dengan jalan retailer menawarkan pelayanan yang baik dan sebagai balasan atas pelayanan yang baik ini. Perlindungan di sajikan sebagai perlakuan yang positif yang diperlakukan oleh retailer kepada konsumen atau pelanggan. Dalam pelaksanaannya aspek perilaku memberikan gambaran beberapa fokus yang mengukur perlindungan termasuk kepuasan konsumen yang mendalam di dalamnya termasuk juga peranan Word of mouth hal ini dikemukana oleh. (Thiruvenkada, Hari, \& Panchanatham, 2014). Secara konsekuen di penelitian ini digunakan pendekatan multidimensional untuk mengukur perlingan retail dan perbedaan secara spesifik WOM, branding, pricing akan memberikan intesitas perlindungan retail yang kokoh dimana ketiganya memiliki effek besar bagi perkembangan keilmuan selanjutnya.

\section{Perilaku Berbelanja Hedonis.}

(Fenouillet, 2012) dalam kajiannya menyatakan bahwa " Hedonic motivation refers to the process that lead the people to behave as they do. It occur when need is aroused that the customer wishes to satisfy." (Chuang, Tian, \& Lin, 2015) mendefinisikan motivasi adalah "the driving force within individual that impulse them to action"sehingga dapat disimpulkan motivasi adalah pendorong yang mengakibatkan seseorang melakukan suatu aktivitas tertentu. Dalam dunia pemasaran motivasi seorang konsumen timbul karena upayanya mencapai tingkat kepuasan tertentu

Alasan dikembangkannya shopping motivation adalah bahwa dalam aktivitas belanja seseorang termotivasi oleh berbagai kebutuhan psikologis disamping juga factor dari nilai guna suatu produk. shopping motivation telah dipelajari dan disusun berdasarkan tipologi motivasi yang dikemukakan oleh (Kusuma, Idrus, \& Djazuli, 2013) menurut tipologi motivasi tersebut shopping motives dapat dikelompokkan menjadi tiga kategori:

1. Motif orientasi produk, mengunjungi toko untuk kebutuhan pembelian atau keinginan untuk mendapatkan informasi produk

2. Motif pengalaman berorientasi pada hedonis atau rekreasi yaitu sebuah toko atau pusat perbelanjaan dikunjungi untuk kesenangan yang melekat pada kunjungan itu sendiri.

3. Motif kombinasi dari orientasi produk dan pengalaman

Menurut (Sreya \& Raveendran, 2016) “ shopping thus occur when a consumer need for a particular good is sufficient for allocating time and money to travel a store to go shopping or when a customer need attention want similar interest feel a need to exercise or simply has leisure time" pengertiannya adalah aktivitas belanja terjadi ketika kebutuhan konsumen untuk barangbarang tertentu cukup untuk waktu dan uang yang dialokasikan untuk bepergian ke sebuah toko atau pergi berbelanja.

Adanya ketidak cocokan ini maka hasil nya adalah pengaktifan suatu kondisi yang 
diekspresikan dalam perilaku dan pembelian menghasilkan dua manfaat :

Pertama Utilitarian needs, merupakan atribut produk fungsional yang efektif. Yang kedua Hedonis need, respon kesenangan, emosional, panca indera dan pertimbangan estetis. Kriteria yang digunakan sewaktu mempertimbangkan manfaat hedonis bersifat subyektif dan simbolik berpusat pada pengertian akan produk atau jasa demi pengertian itu sendiri terlepas dari pertimbangan yang lebih obyektif.

Kebutuhan Hedonis ini lebih menjadi sorotan utama karena dalam memperhatikan kondisi dari pengunjung terlihat bahwa ada sesuatu misteri yang harus diungkapkan untuk dapat dijadikan sebagai dasar dalam penyusunan strategi yang dilakukan oleh suatu perusahaan. Hedonisme adalah suatu paham yang dimiliki oleh seseorang berdasar pada suatu kesenangan semata-mata yang difokuskan demi memenuhi kepuasan pikiran dari orang yang bersangkutan.

Menurut (Davis \& Hodges, 2012) nilai berbelanja berorientasi pada dua motivasi Hedonis yaitu nilai Utilitarian dan motivasi Hedonis. Nilai Utilitarian mewakili untuk orientasi pada tugas yang harus dilakukan sedangkan nilai Hedonis mengungkapkan kepuasan seseorang dan pergaulan seseorang dengan pengalaman berbelanja. Menurut (Hartono Subagio, 2011) motif Hedonis shopping didasarkan pada kualitas dari pengalaman belanja itu sendiri daripada pengumpulan dari suatu informasi atau suatu pembelian produk. Hedonis shopping merupakan suatu keinginan seseorang untuk mendapatkan suatu kesenangan bagi dirinya sendiri yang dapat dipenuhi dengan cara menghabiskan waktu untuk mengunjungi pusat perbelanjaan atau mall, menikmati suasana atau atmosfer yang ada di pusat perbelanjaan itu sendiri meskipun mereka tidak membeli atau hanya melihat lihat saja.

\section{Store Environment.}

Store Enviroment merupakan unsur penting dalam Retailing mengingat bahwa $70 \%$ dari pembelian ternyata merupakan Impulse buying atau pembelian yang tidak direncanakan (Nanda, 2013). Melalui element element yang ada di dalam Store Environment, retailer dapat menciptakan stimuli-stimuli yang akan memicu atau menggerakkan pelanggan untuk lebih banyak membeli barang di luar rencana mereka. Store Environment yang dirancang dengan baik dan sesuai dengan target market yang ditetapkan akan dapat menciptakan emosi atau suasana hati yang kondusif untuk berbelanja. Teori mengenai Store Environment dalam hal ini akan lebih mengacu pada teori yang dikemukakan oleh (Chuang et al., 2015). Tidaklah mungkin sebuah toko bisa dibagi bagi menjadi beberapa kategori atau department kecuali toko tersebut hanya mempunyai spesialisasi untuk satu macam produk saja. Sebagai gambaran pelanggan tidak akan tahu harus mulai berbelanja dari mana. Sebuah gerai akan hanya seperti lautan rak dan barang yang akan menyulitkan pelanggan untuk berbelanja. Tak kalah pentingnya yaitu visual display dan focal point dimana barang yang disajikan akan ditempatkan di daerah yang strategis untuk menarik perhatian pelanggan. Sebuah toko retail harus dilengkapi dengan petunjuk petunjuk yang dapat membantu dan mengarahkan pelanggan dengan mudah untuk menjelajahi seluruh toko. Sekali saja seorang pelanggan sedikit bingung tentang dimana mereka berada, kemana mereka harus pergi dan berapa harga barang yang ditetapkan kemungkinan mereka akan frustasi dan apabila kejadian tersebut berulang ulang maka pelanggan akan menarik kesimpulan bahwa toko tersebut bukan tempat yang mudah dan nyaman untuk berbelanja. Dalam Retailing istilah store planning adalah sebuah skematis yang menunjukkan dimana barang barang dan pusat layanan berada, bagaimana sirkulasi pelanggan di dalam gerai dan seberapa banyak ruang yang dialokasikan untuk tiap tiap department. Hal ini sama pentingnya dengan menempatkan barang barang di tempat yang tepat adalah mengurangi stack out yaitu barang barang yang dipajang di lantai di depan dan di rak utama dapat meningkatkan penjualan barang yang memiliki keterkaitan dengan barang tersebut. Mengingat bahwa $70 \%$ pembelian adalah impulse atau tidak direncanakan (Sachdeva \& Goel, 2015). Terkait dengan hal ini maka Retailer akan mengalami penurunan penjualan karena pelanggan tidak melewatkan beberapa hal utama dalam aspek perancangan sebuah floor plan yang terdiri dari alokasi ruangan, 
Pengaturan sirkulasi, dan pengurangan penyusutan.

\section{Konsep Meta Analisis}

Merupakan suatu pendekatan statistik ke arah studi agregasi pada penelitian yang sifatnya independent. (Eisend \& Tarrahi, 2014) mendefinisikan Meta Analisis sebagai suatu metode sistematis yang menggunakan analisis statistik dengan menggabungkan data dari penelitian independent untuk mendapatkan estimasi numerik dari efek keseluruhan suatu prosedur tertentu atau variabel pada hasil yang ditetapkan. Dalam kasus ini Meta Analisis mengacu pada analisis sekunder temuan, karena data berasal dari penelitian sebelumnya yang telah dipublikasikan. Perlu dicacat bahwa analisis ini bukanlah metode tunggal tetapi sebuah pendekatan untuk merangkum temuan. Menurut (Brei, Vieira, \& Matos, 2014) Meta Analisis adalah Teknik yang digunakan untuk merangkum berbagai hasil penelitian secara kuantitatif dengan cara menilai efek size. Efek size dicari dengan cara menelaah selisih rata rata kelas ekperimen dengan rata rata kelas control kemudian dibagi dengan standar deviasi kelas control.

(Edeling \& Fischer, 2016) menyatakan secara sederhana Meta Analisis dapat diartikan sebagai analisis atas analisis yang bersangkutan sebagai penelitian lanjutan. Meta Analisis merupakan kajian atas sejumlah hasil dalam masalah penelitian sejenis, Meta Analisis merupakan salah satu cara membuat rangkuman hasil penelitian secara kuantitatif. Gagasan Meta Analisis muncul dari pendapat (Simbrunner \& Schlegelmilch, 2017) dimana disajikan dalam penemuan psikolog Amerika yang mana dalam penerapannya Meta Analisis ingin menjawab apakah ada perbedaan antara kelompok percobaan dan kelompok pembanding. Jika dibandingkan dengan hasil penelitian yang terus bertambah dari tahun ke tahun.

(Eisend, 2015) mengatakan Meta Analisis merupakan suatu Analisa integratif sekunder dengan menerapkan prosedur statistik terhadap hasil pengujian hipotesis penelitian. Analisis sekunder yang dihasilkan merupakan analisis ulang (reanalysis) terhadap data dengan tujuan menjawab pertanyaan baru dengan data lama yang dimiliki. Analisis sekunder merupakan suatu ciri penting terhadap riset dan kegiatan evaluasi. (Edeling \& Fischer, 2015) mengatakan bahwa sifat Meta Analisis lain kuantitatif dan memakai analisis statistik untuk memperoleh seri informasi yang berasal dari sejumlah data dari penelitian penelitian sebelumnya. Menurut (Albers, Mantrala, \& Sridhar, 2010) bahwa Meta Analisis merupakan teknik pengembangan paling baru untuk menolong peneliti menemukan konsistensi atau hal yang tidak konsisten dalam mengkaji dari hasil silang penelitian. Secara sederhana. Meta Analisis dapat diartikan sebagai analisis atas analisis atau dengan kata lain merupakan kajian atas sejumlah hasil penelitian dalam masalah yang sejenis. Kajian ini pada hakekatnya merupakan sintesis sebuah topik yang diambil dari beberapa laporan penelitian. Berdasarkan sintesis tersebut ditarik sebuah kesimpulan mengenai topik yang diteliti dengan melihat signifikansi suatu treatment atau intervensi terhadap suatu mode permasalahan lebih lanjut.

\section{Gambar 1 Kerangka Konseptual.}

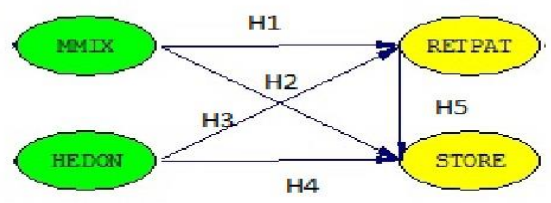

Hipotesis.

H1 : Marketing Mix berpengaruh terhadap Perlindungan Retail. (Blut, Teller, \& Floh, 2018)

H2 : Marketing Mix berpengaruh terhadap Store Environment (Tendai \& Crispen, 2009) H3 :Perilaku Hedonis berpengaruh terhadap Perlindungan Retail (Telci, 2013)

H4 : Perilaku Hedonis berpengaruh terhadap Store Enviroment (Ashley, Ligas, \& Chaudhuri, 2010)

H5 : Perlindungan Konsumen berpengaruh terhadap Store Environment (Kumar, 2016)

\section{METODE}

Metode analisis dalam penelitian ini dapat dilihat pada Gambar 1 dimana digambarkan hubungan yang akan dianalisis dan pengaruh hubungan antara Observed variabel dan Manifest variabel. Skala pengukuran yang digunakan pada penelitian ini adalah 
menggunakan skala Likert 5 point dengan (1) "sangat tidak setuju" sampai (5) "sangat setuju". Instrumen yang dipakai untuk mengumpulkan data adalah daftar pertanyaan berupa kuesioner yang akan disebarkan kepada konsumen dan pelanggan gerai retail Top 100 di wilayah Batam. Metode pengumpulan data yang akan dipakai adalah dengan menyebarkan langsung kepada konsumen retail tersebut.

Karakteristik dan Batasan populasi untuk mengumpulkan data yang diperlukan dalam penelitian ini adalah konsumen Top 100 Supermarket yang berumur 19- 45 tahun. Teknik sampling yang digunakan dalam penelitian ini adalah Accidental Sampling dimana pengambilan sampel dilakukan secara tiba-tiba, sehingga seluruh anggota populasi bisa diminta informasi dan wawancara secara langsung. Hal ini dilakukan agar tidak mengganggu aktivitas responden dimana responden memiliki kesempatan yang sama untuk dijadikan sampel. Sesuai dengan model analisis yang telah dijelaskan di atas maka pengolahan dan analisis data dilakukan dengan menggunakan teknik Multivariat Structure Equation Model (SEM), dimana dalam pengolahan data menggunakan alat bantu analisis software Lisrel 8.8 For Windows. Tahap tahap pengolahan data dengan bantuan software tersebut dapat dilihat pada gambar di bawah

Gambar 2 Manifested Variabel.

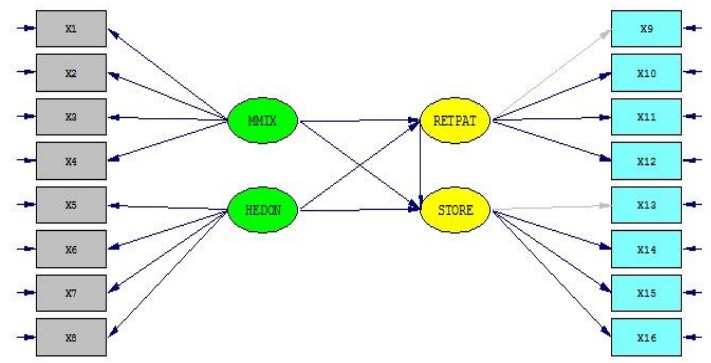

\section{HASIL PENELITIAN DAN PEMBAHASAN}

jumlah kuesioner yang disebarkan sebanyak 250 eksemplar, setelah terjun ke lapangan jumlah kuesioner yang dikembalikan adalah 50\% saja yaitu 126 eksemplar. Tingkat pengembalian yang rendah ini disebabkan karena banyak konsumen gerai Top 100 supermarket. dari 120 eksemplar yang dikembalikan hanya 6 orang yang mengisi tidak lengkap sehingga hanya 120 koesioner yang memenuhi syarat untuk dianalisis lebih lanjut. Untuk lebih jelasnya profil konsumen gerai yang menjadi responden ini secara lengkap dapat dilihat pada tabel di bawah ini:

\section{Tabel 1 Deskripsi Responden \\ Tabel 1. \\ Deskripsi \\ Responden}

\begin{tabular}{lcc}
\hline & Jumlah & $\begin{array}{c}\text { \% dari seluruh } \\
\text { responden }\end{array}$ \\
\hline jenis kelamin: & & \\
laki laki & 64 & 53.3 \\
perempuan & 56 & 46,6 \\
tidak diisi & 8 & 6,6 \\
usia: & & \\
$<30$ & 34 & 14,6 \\
30-39 & 35 & 29,1 \\
$>40$ & 51 & 42.5 \\
tidak diisi & 7 & 5,8 \\
jenjang & & \\
pendidikan : & & \\
diploma & 30 & 25 \\
S1 & 75 & 62.5 \\
S2 & 15 & 12.5 \\
tidak diisi & 9 & 7.5 \\
masa kerja: & & \\
$<5$ tahun & 45 & 37.5 \\
5 - 10 tahun & 53 & 44,1 \\
11 - 20 tahun & 22 & 18,3 \\
$>$ 20 tahun & 0 & 0 \\
\hline Sumber: & &
\end{tabular}

\section{Sumber : data}

diolah 2018)

Dalam penelitian ini jumlah reponden yang memenuhi syarat untuk dianalisis sejumlah 120 dan jumlah seluruh variabel manifest adalah 16 sedankan rule of thumb untuk perbandingan jumlah sampel terhadap jumlah indikator adalah 1:5 (Kurniawan, Loekito, \& Solimun, 2016). Jadi jika indikator dalam penelitian ini sebanyak 16 maka minimal sampel yang dibutuhkan adalah minimal 80. (Ghozali, 2011) mengemukakan bahwa jumlah sampel minimal untuk SEM adalah 100- 200, karena jumlah sampel untuk dilakukan pengolahan secara single step maka jalan keluar kedua digunakan two step. Menurut (Hair, 2009) pengujian validitas adalah pengujian untuk mengetahui kemampuan indikator-indikator suatu 
konstruks (variabel laten) untuk mengukur konstruks tersebut secara akurat. Ada dua hal yang dilakukan dalam pengujian validitas yaitu pemeriksaan terhadap nilai "t" dan pemeriksaan terhadap tingginya muatan factor standard atau $\lambda$ (standardize loading factor). Muatan factor untuk masing masing indicator terhadap variabel latennya disajikan dalam bentuk hubungan yang digambarkan dalam bentuk hubungan yang digambarkan dalam diagram path yang diperoleh dengan menjalankan program LISREL.

Setelah menjalankan program LISREL untuk tiap variabel (MMIX, HEDON, RETPAT, STORE) secara berurutan maka diketahui nilai $\mathrm{t}$ dan $\lambda$ dari indikator pada masing masing variabel laten tersebut berada di atas nilai kritis yaitu >1,96 untuk nilai $\mathrm{t}$ dan 0,30 untuk nilai $\lambda$. Kecuali indikator STORE 3 untuk variabel laten STORE dibawah batas kritis yaitu sebesar 2,67 dan 0,53 hal ini menunjukkan bahwa indikator indikator tiap variabel laten memenuhi kriteria sebagai indikator yang valid untuk merepresentasikan tiap variabel laten yang diwakilinya.

Pengujian reliabilitas secara langsung dari output LISREL dilakukan dengan melihat nilai $\delta$ untuk variabel exogen dan $\varepsilon$ untuk variabel endogen. Dari diagram path yang dihasilkan oleh LISREL dapat dinilai bahwa nilai measurement error tiap variabel indicator sangat rendah yaitu di bawah $<0,30$. Pengujian secara tak langsung menggunakan dua parameter yaitu construct reliability dan variance extract. Perhitungan secara lengkap dapat dilihat angkuman hasil akhir pada tabel 2 berikut ini:

Tabel 2. Reliabilitas

\begin{tabular}{lcc}
\hline \multirow{2}{*}{$\begin{array}{c}\text { Variabel } \\
\text { laten }\end{array}$} & \multicolumn{2}{c}{ Parameter } \\
\cline { 2 - 3 } & $\begin{array}{c}\text { Construct } \\
\text { Reliability }\end{array}$ & $\begin{array}{c}\text { Variance } \\
\text { Extract }\end{array}$ \\
\hline MMIX & 0,78 & 0,81 \\
HEDON & 0,86 & 0,79 \\
RETPAT & 0,89 & 0,54 \\
STORE & 0,82 & 0,72 \\
\hline
\end{tabular}

Sumber: Data diolah

(2018)

Dari tabel 2 diatas dapat dilihat bahwa nilai Construct Reliability tiap variabel berada di atas batas kritis yaitu >0,5 kecuali variabel laten.
Sedangkan untuk variance extracted 4 variabel laten berada di atas batas kritis juga adalah variable laten Marketing Mix (MMIX) sebesar 0,78 dengan nilai Construct Reliability dan Variance Extract tidak berada di batas kritis berarti bahwa variabel indikator memiliki konsistensi pengukuran yang baik terhadap variabel laten yang diwakilinya. Sebagai bahan pembanding dengan hasil yang diperoleh jurnal acuan (Blut et al., 2018) dapat dilihat dari tabel 3 sebagai berikut:

Tabel 3. Kesesuaian Model Struktur

\begin{tabular}{lc}
\hline variabel laten & $\begin{array}{c}\text { R } \\
\text { square }\end{array}$ \\
\hline MMIX & \\
HEDON & 0.72 \\
RETPAT & 0.82 \\
STORE & 0.83 \\
\hline
\end{tabular}

sumber data diolah 2018)

Dari hasil pengukuran reliabilitas dengan empat parameter variabel MMIX,HEDON,RETPAT dan STORE terbukti reliabel pada tiap parameter. Variabel HEDON meskipun nilai measurement error sangat tinggi $(0,82)$ pada salah satu variabel manifestnya HED 3 tetapi diimbangi oleh nilai Construct Reliability dan Variance Extract yang tinggi yaitu 0,78 dan 0,81 sehingga variabel HEDON dan RETPAT terbukti reliabel ,dua parameter yaitu measurement error dan varian ectract di atas batas kritis tetapi parameter Construct Reliability lebih besar dari batas kritis $(0,82$ $>70$ sehingga tetap reliabel.

\section{Pengujian Hipotesis}

Ke lima hipotesis penelitian dituangkan ke dalam dua persamaan adalah sebagai berikut:

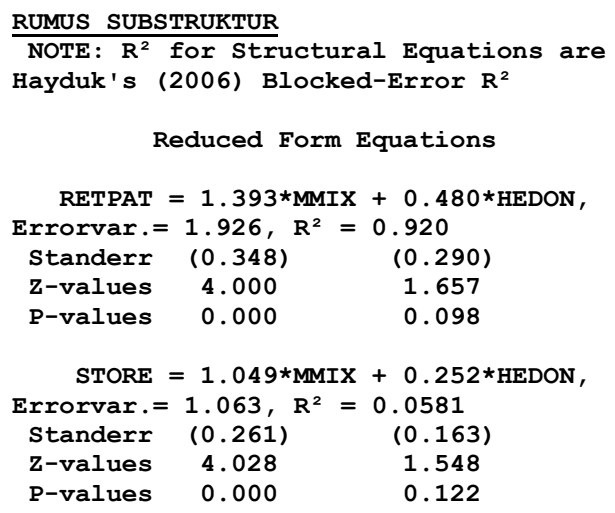


Pengujian hipotesis penelitian dilakukan dengan menguji hubungan antar variabel laten seperti persamaan 1-2 dan untuk menguji hubungan antar variabel laten diperlukan Score Factor dari setiap variabel laten tersebut, perlu diperhatikan bahwa kedua model struktural 1 dan 2 diuji secara serentak. Berikut ini adalah hasil pengujian hipotesis: H1 menyatakan Marketing mix berpengaruh terhadap perlindungan retail dan direpresentasikan dengan persamaan (1) hasil pengujian H1 dengan LISREL:

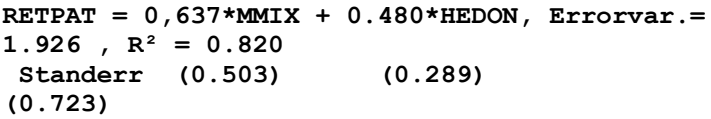

Dengan nilai t sebesar 0,503 yang besarnya jauh di atas batas kritis maka pengaruh yang diberikan variabel MMIX memberikan pengaruh sebesar 0,637 terhadap RETPAT terbukti signifikan

H2 menyatakan Marketing mix berpengaruh terhadap Store Environment diperkuat oleh retail Patronage dan hipotesis kedua dinyatakan dalam persamaan hasil pengujian H2 dengan LISREL:

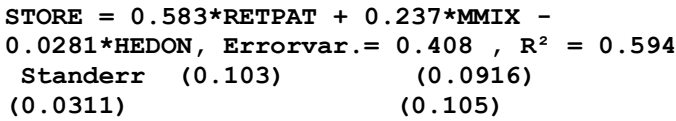

Dari rumus persamaan di atas terlihat bahwa nilai $\mathrm{t}$ variabel 0,103 berada jauh di bawah batas kritis bahkan bernilai negatif. Nilai koefisien yaitu 0,237 dengan nilai validitas $R$ square yang dimiliki tinggi yaitu 0,594 berarti nilai Marketing MIX hanya perlu memberikan pengaruh sebesar 0,237 terhadap Store Enviroment karena tidak siginifikan secara statistik maka variabel laten MMIX dikeluarkan kemudian program LISREL dijalankan lagi. Sehingga diperoleh hasil sebagai berikut:

STORE $=0.576 \star_{\text {RETPAT }}+0.328 \star_{\mathrm{HEDON}}$,

Errorvar. $=0.408, R^{2}=0.594$

Standerr (0.523) (0.691)

$(0.411)$

$(0.405)$

Persamaan di atas mengasilkan nilai $\mathrm{t}$ dan variabel baru untuk variabel Store Enviromnet Besarnya nilai $t$ melewati batas kritis yaitu 0,523 sehingga terbukti memberikan pengaruh yang siginifikan. Sedangkan koefisien yang dimiliki MMIX turun 0,576 dari 0,583 pada persamaan mula mula menjadi 0,408 pada persamaan baru. Dengan demikian telah dibuktikan bahwa hipotesis $\mathrm{H} 2$ terpenuhi (terbukti).

Hipotesis H3 menyatakan bahwa Perilaku hedonis berpengaruh terhadap perlindungan retail dan hipotesis $\mathrm{H} 3$ menyatakan bahwa HEDON berpengaruh terhadap penerimaan STORE. Hipotesis tersebut dinyatakan dalam persamaan (2) hasil pengujian $\mathrm{H} 3$ dan $\mathrm{h} 3 \mathrm{~b}$ dengan menggunakan LISREL:

STORE $=0.583 *$ RETPAT $+0.237 *$ MMIX -

$0.0421 *$ HEDON, Errorvar. $=0.408, R^{2}=0.594$

Standerr (0.103) (0.0916)

$(0.0311) \quad(0.105)$

Persamaan di atas menunjukkan bahwa variabel HEDON tidak signifikan secara statistik karena nilai $\mathrm{t}$ yang dimiliki masih sangat kecil yaitu 0,105 Variabel STORE tidak memiliki nilai $\mathrm{t}$ di atas nilai kritis yaitu sebesar. Tapi karena nilai $t$ variabel HEDON tidak terlalu jauh dari batas kritis >0,50 maka untuk pengujian ulang variabel HEDON tetap digunakan setelah program LISREL dijalankan maka kembali hasil yang diperoleh adalah sebagai berikut:

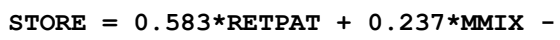

$0.453 *$ HEDON, Errorvar. $=0.408, \mathrm{R}^{2}=0.594$

Standerr (0.603) (0.416)

$(0.405)$

Setelah HED5 (variabel manifested) dihilangkan maka persamaan baru menunjukkan bahwa nilai t variabel HEDON telah meningkat menjadi 0,531 berarti telah melewati batas kritis dan terbukti signifikan dalam mempengaruhi Store Environment sedangkan koefisien yang dimiliki hanya meningkat sedikit yaitu menjadi 0,453 yang berarti persepsi pengguna terhadap penggunaan Store Environmnet meningkat dan memberikan pengaruh sebesar 0,453 terhadap penerimaan konsumen gerai meskipun besarnya $\mathrm{R}$ square < 1 yang berarti model hanya menjelaskan kurang dari $1 \%$ perubahan yang terjadi tetapi pengaruh tersebut tetapada dan hubungan kedua variabel tersebut signifikan secara statistik. jadi hipotesis $\mathrm{H} 2$ diterima dan di sisi lain hipotesis $\mathrm{H} 3$ diterima meskipun tidak cukup baik tetapi tetap signifikan. Sehingga dapat diterima.

Dalam SEM ada 3 uji kesesuaian yang dilakukan yaitu: pengujian kesesuaian 
model secara menyeluruh: (Overall model fit), pengujian kesesuaian model pengukuran (Measurement model fit) dan pengujian kesesuain model structural (Structural model fit). Pengujian kesesuaian model pengukuran telah dilakukan pada bagian sebelumnya. Karena berkaitan dengan Validitas dan Reliabilitas. Dengan menjalankan program LISREL untuk menguji kesesuain model maka dihasilkan bentuk akhir diagram Structural model fit hubungan antar variabel laten secara keseluruhan seperti pada gambar berikut ini:

\section{Gambar 2 Structural Model Fit Overall}

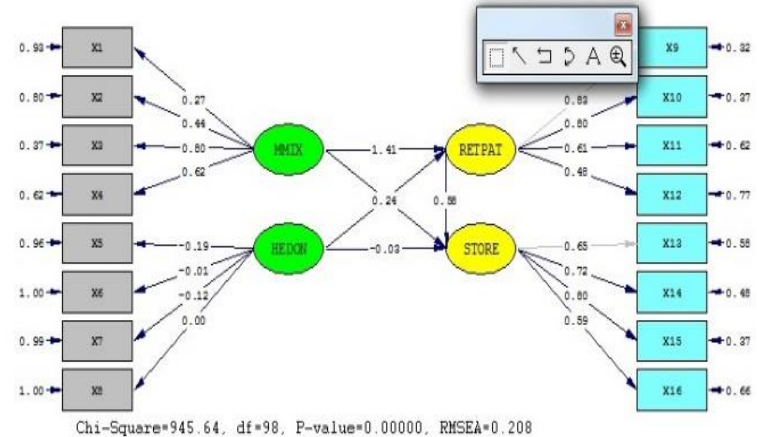

Pengujian atas kesesuaian model keseluruhan akan dilakukan menggunakan indicator Godness of fit indices (GFI), GFI dipilih karena merupakan parameter (indicator) yang umum digunakan dalam menguji kesesuaian model keseluruhan selain itu sebagai pembanding juga digunakan Normed fit index dan Comparative fit index (NFI) yang didapatkan langsung dari output LISREL, besarnya nilai masing masing akan disajikan dalam tabel di bawah ini:

\section{Tabel 4. Godness Of Fit}

\begin{tabular}{lc}
\hline Overall model fit untuk: & NILAI \\
\hline DEGREES OF FREEDOM & 98 \\
NCP & 847,6 \\
RMSEA & 0,208 \\
ECVI & 5,108 \\
NFI & 0,443 \\
CFI & 0,463 \\
GFI & 0,720 \\
AGFI & 0,612
\end{tabular}

sumber: data diolah (2018)

Secara keseluruhan hasil pengujian model keseluruhan berada di atas nilai 0,80 kecuali pada model pengukuran variabel laten MMIX terhadap STORE indikator GFI $=0,720$ tetapi masih diimbangi dengan nilai $\mathrm{NFI}=0,443$ dan $\mathrm{CFI}=0,463$ kesesuain model keseluruhan (overall model fit). Secara keseluruhan model yang dispesifikasi memiliki tingkat kesesuain dengan variabel manifest dan variabel laten yang mendasarinya. Menunjukkan bahwa modelyang diusulkan mempunyai tingkat kesesuaian menyeluruh cukup bagus kecuali untuk hubungan variabel manifes terhadap laten variabel STORE, tetapi menurut Ghozali, (2011) nilai GFI dan NFI di atas $>0,70$ sudah cukup tinggi. Dengan demikian model struktur yang dispesifikasikan memiliki tingkat kesesuaian yang cukup tinggi

Indikator dari kesesuaian model struktur yang diajukan sama seperti dalam model path yaitu $\mathrm{R}$ square dari keseluruhan hipotesis menghasilkan 2 persamaan berarti ada 2 model struktural yang diajukan. Tetapi pada pengujian hipotesis model ke 2 direduksi sehingga model struktural yang layak untuk melanjutkan pengujian kesesuain model adalah sebagai berikut:

Rumus persamaan substruktur 1

RETPAT $=1.393 *$ MMIX $+0.480 *$ HEDON, Errorvar $=$ $1.926, R^{2}=0.920$

standerr $(0.348)$

$(0.290)$

Rumus persamaan substruktur 2

STORE $=1.049 \star_{M M I X}+0.252 *$ HEDON, Errorvar. $=$

$1.063, \mathrm{R}^{2}=0.0581$

Standerr $(0.261)$

$(0.163)$

\section{SIMPULAN}

Penelitian ini memberikan beberapa implikasi bagi organisasi organisasi yang sudah ada ataupun baru akan menerapkan teknologi informasi secara umum khususnya yang berkaitan dengan bisnis retail dalam skala kecil. Penelitian ini dapat menjadi acuan untuk melakukan penelitian baik kepentingan Pendidikan ataupun untuk kepentingan praktisi dalam mengukur tinggi rendahnya minat kunjungan ke gerai ritail terhadap lingkungan dan suasana gerai yang ditawarkan pihak yang bersangkutan.

\section{DAFTAR PUSTAKA}

Albers, S., Mantrala, M. K., \& Sridhar, S. (2010). Personal Selling Elasticities: A Meta-Analysis. Journal of Marketing Research, 47(5), 840-853. https://doi.org/10.1509/jmkr.47.5.840

Ashley, C., Ligas, M., \& Chaudhuri, A. (2010). Can Hedonis Store Environments Help Retailers Overcome 
Low Store Accessibility? The Journal of Marketing Theory and Practice, 18(3), 249-262. https://doi.org/10.2753/MTP10696679180303

Blut, M., Teller, C., \& Floh, A. (2018). Testing Retail Marketing-Mix Effects on Patronage: A Meta-Analysis. Journal of Retailing.

https://doi.org/10.1016/j.jretai.2018.03.0 01

Brei, V. A., Vieira, V. A., \& Matos, C. A. de. (2014). Meta-Analysis In Marketing. Revista Brasileira de Marketing, 13(2), 84-97. https://doi.org/10.5585/remark.v13i2.26 81

Chuang, C.-L., Tian, H.-L., \& Lin, R.-H. (2015). Applicability of Prospect Theory on Impulse Buying Intention and Relationship between Impulse Buying Tendency and Impulse Buying Intention. Xing Xiao Ping Lun, 12(1), 99-127.

Davis, L., \& Hodges, N. (2012). Consumer shopping value: An investigation of shopping trip value, in-store shopping value and retail format. Journal of Retailing and Consumer Services, 19(2), 229-239. https://doi.org/10.1016/j.jretconser.2012. 01.004

Edeling, A., \& Fischer, M. (2015).

Marketing's Impact on Firm ValueGeneralizations From a Meta-Analysis. Journal of Marketing Research. https://doi.org/10.1509/jmr.14.0046

Edeling, A., \& Fischer, M. (2016).

Marketing's Impact on Firm Value: Generalizations from a Meta-Analysis. Journal of Marketing Research, 53(4), 515-534. https://doi.org/10.1509/jmr.14.0046

Eisend, M. (2015). A Meta-Meta-Analysis of Effect Sizes in Marketing Research. Journal of Marketing, 79(May), 23-40.

Eisend, M., \& Tarrahi, F. (2014). Metaanalysis selection bias in marketing research. International Journal of Research in Marketing, 31(3), 317-326. https://doi.org/10.1016/j.ijresmar.2014.0 3.006

Ertekin, S. (2009). An assessment of consumers' willingness to patronize foreign-based business format franchises: An investigation in the fastfood sector. ProQuest Dissertations and Theses. https://doi.org/10.1007/978-3319-11797-3_81

Fenouillet, F. (2012). The hedonis conceptions of motivation. Pratiques Psychologiques, 18(2), 121-131. https://doi.org/10.1016/j.prps.2012.02.00 3

Fieger, P. (2015). REGULATION OF ECOMMERCE INTERMEDIARIES: AN INTERNATIONAL PERSPECTIVE. Journal Of The Bertrand Russell Archives, 49(January), 1-31.

Ghozali, I. (2011). Moderated Structural Equation Modeling. In Model persamaan struktural. Konsep dan aplikasi dengan program AMOS 19.0 (pp. 180-183).

Hair, J. (2009). Multivariate Data Analysis. Faculty Publications.

Hartono Subagio. (2011). Pengaruh Atribut Supermarket Terhadap Motif Belanja Hedonik Motif Belanja Utilitarian Dan Loyalitas Konsumen. Jurnal Manajemen Pemasaran, 6(1), 8-21.

Hasslinger, A., Hodzic, S., \& Opazo, C. (2007). Consumer Behaviour in Online Shopping. Online.

Kumar, P. (2016). Store decision criteria and patronage behaviour of retail consumers. International Journal of Management Research and Review, 6(12), 16921703.

Kurniawan, A., Loekito, L., \& Solimun, S. (2016). Power Of Test Path Analysis and Partial Least Square Analysis.

CAUCHY; Vol 4, No 3 (2016): CAUCHYDO - 10.18860/ca.v4i3.3593, 4(3), 112-114.

Kusuma, G. W., Idrus, S., \& Djazuli, A. (2013). The Influence of Hedonis Shopping Motivations on Buying Decision with Gender as Dummy Variable: (A Study on Consumers at the Hardy's Mall Singaraja, Buleleng Regency, Indonesia). European Journal of Business and Management, 5(31), 241-246.

Nanda, A. (2013). Impulse Buying of Apparels. International Journal of Research in Commerce and Management, 4(2), 170-176.

Novak, D. (2011). Promotion As Instrument 
of Marketing Mix. I International Symposium Engineering Management And Competitiveness, 2011, 505-510.

Reddy, C. S., \& Aradhya.S, G. B. (2017). Factors Affecting Online Shopping Behaviour of Consumers. European Journanl of Social and Human Sciences, 1(17), 59-61.

Sachdeva, I., \& Goel, S. (2015). Retail Store Environment and customer experience: a paradigm Retail Store Environment and customer experience: a paradigm. Journal of Fashion Marketing and Management Journal of Fashion Marketing and Management: An International Journal, 19(2), 290-298. https://doi.org/10.1108/JFMM-03-20150021

Sari, Yuli Kumala; Shaari, Zullina Hussain; Amar, A. Bin. (2017). Measurement Development of Customer Patronage of Petrol Station with Convenience Store. Global Business \& Management Research, 9, 52-63.

Simbrunner, P., \& Schlegelmilch, B. B. (2017). Moral licensing: a culturemoderated meta-analysis. Management Review Quarterly, 67(4), 201-225. https://doi.org/10.1007/s11301-0170128-0

Sreya, R., \& Raveendran, P. T. (2016). Effect of Shopping Orientations on Attitude Towards Online Shopping- a Multiple Regression Approach. Management Insight, XII(2), 51-57. https://doi.org/10.21844/mijia.v12i02.69 72

Telci, E. E. (2013). High shopping mall patronage: Is there a dark side? Quality and Quantity, 47(5), 2517-2528. https://doi.org/10.1007/s11135-0129668-5

Tendai, M., \& Crispen, C. (2009). In-store shopping environment and impulsive buying. African Journal of Marketing Management, 1(4), 102-108.

Thiruvenkada, T., Hari, K., \& Panchanatham, N. (2014). Model of Store Patronage Behaviour using SEM Approach. Journal of Commerce (22206043), 6(1), 13-31. 